\title{
Kualitas Audit, Kondisi Keuangan, Ukuran Perusahaan dan Penerimaan Opini Audit Going Concern
}

\author{
Bahtiar Effendi \\ Matana University, Tangerang, Indonesia \\ bahtiar.effendi@matanauniversity.ac.id
}

\begin{abstract}
This study aims to analyze the quality of audits, financial condition and firm size on audits that occur in companies listed on the Indonesia Stock Exchange period 2014-2016. The population of this research is all transportation company in Indonesia year 2014-2016. The number of samples were 14 transportation companies, selected using purposive sampling method. This study uses data collected from Indonesia Stock Exchange (BEI) in 2014-2016 and also from each company website. By using multiple analysis as the method and result of this research, deep audit can be done.
\end{abstract}

Keywords: audit quality, financial condition, company size acceptance of going concern audit opinion.

\section{PENDAhuluan}

Tujuan suatu perusahaan didirikan tidak hanya untuk mencari keuntungan, tetapi juga untuk mempertahankan going concern (kelangsungan hidup). Penelitian ini dilakukan dengan tujuan untuk melihat apakah kualitas audit meningkatkan kemungkinan sebuah perusahaan yang mengalami financial distress (kesulitan keuangan) menerima pendapat wajar dengan qualifies opinion (pengecualian) untuk going concern (kelangsungan usaha). Independensi auditor dalam memberikan opini atas laporan keuangan yang diauditnya harus mempertimbangkan going concern (kelangsungan usaha) auditee. Going concern merupakan asumsi dasar dalam penyusunan laporan keuangan, suatu perusahaan diasumsikan tidak bermaksud atau berkeinginan melikuidasi atau mengurangu secara materian skala usahanya (Standar Akuntansi Keuangan, 2002). Opini audit dengan modifikasi mengenai going concern mengindikasi bahwa dalam penilaian auditor terhadap risiko perusahaan tidak dapat bertahan dalam bisnis normal.
Auditor mengeluarkan opini audit going concern untuk memastikan apakah perusahaan mampu mempertahankan kelangsungan usahanya atau tidak. Opini audit going concern sangat berguna bagi investor untuk menetapkan keputusan investasi. Terkait dengan pentingnya opini audit yang dikeluarkan oleh auditor, maka auditor harus bertanggung jawab untuk mengeluarkan opini audit going concern yang konsisten dengan kondisi yang sebenarnya. Ada beberapa faktor yang berpengaruh terhadap penerimaan opini audit going concern, yaitu: kualitas audit, kondisi keuangan dan ukuran perusahaan.

Banyak kasus manipulasi laporan keuangan yang terjadi, membuat para akuntan publik mendapat kritikan. Auditor dianggap ikut berperan dalam memberikan informasi yang salah, sehingga dapat merugikan banyak orang. Kemudian, AICPA (dalam Januarti, 2007) mensyaratkan bahwa auditor harus mengemukakan secara eksplisit apakah perusahaan klien dapat mempertahankan kelangsungan hidupnya sampai setahun kemudian setelah tanggal pelaporan. Auditor tidak memiliki tanggung jawab atau 
kelangsungan hidup suatu perusahaan, namun kelangsungan hidup perusahaan menjadi pertimbangan bagi auditor untuk memberikan pendapatnya.

Penelitian ini didasarkan pada fenomena yang terjadi yaitu mengenai kasus yang terkait dengan going concern pada tahun 2012, Batavia Air tidak bisa membayar hutang sebesar \$4,68 juta yang akan jatuh tempo pada 13 Desember 2012, Batavia Air tidak melakukan pembayaran hingga akhirnya pihak kreditur mengajukan gugatan pailit kepada Batavia Air. Saat sebelum mengalami kebangkrutan, laporan keuangan Batavia Air menunjukkan kemampuan membayar kewajiban jangka pendek serta jangka panjang, dan arus kas dalam kondisi yang baik. Hingga laporan keuangan mendapatkan opini audit yang wajar tanpa pengecualian dan tidak menerima kualifikasi going concern pada tahun 2011. Namun ternyata Batavia Air justru tidak dapat mempertahankan kelangsungan perusahaannya hingga mengalami kebangkrutan. (Fauziah dan Hanifah, 2014).

Berdasarkan penelitian sebelumnya yang dilakukan oleh Santosa dan Wedari (2007), mengatakan bahwa kualitas audit dan pertumbuhan perusahaan tidak berpengaruh terhadap opini audit going concern, namun kondisi keuangan dan ukuran perusahaan berpengaruh negatif terhadap opini audit going concern, dan opini audit sebelumnya berpengaruh positif terhadap opini audit going concern. Sedangkan penelitian yang dilakukan oleh Januarti (2007) menyatakan bahwa kondisi keuangan tidak berpengaruh terhadap opini audit going concern, sedangkan kualitas audit dan ukuran perusahaan berpengaruh terhadap opini audit going concern. Pada penelitian yang dilakukan oleh Kristina (2012), menyatakan bahwa ukuran perusahaan tidak berpengaruh terhadap opini audit going concern.

Peneliti beranggapan bahwa penelitian mengenai opini audit going concern di Indonesia masih menjadi objek penelitian yang penting dan menarik dilakukan karena mengingat bahwa opini audit going concern suatu badan usaha merupakan salah satu hal yang mendasari para investor dalam pengambilan keputusan investasi dan juga para kreditor dalam meminjamkan dananya dengan tujuan untuk memperoleh laba dari aktivitas perusahaan tersebut. Selain itu, opini audit going concern sering dihubungkan dengan kelangsungan hidup usahanya. Berdasarkan fenomena yang terjadi pada salah satu perusahaan yang terjadi yaitu Batavia Air, peneliti tertarik untuk melakukan penelitian pada sektor transportasi yang terdaftar di BEI pada tahun 2014-2016. Peneliti ingin mengetahui bagaimana kelangsungan hidup dari perusahaan sektor Transportasi setelah adanya fenomena tersebut.

\subsection{Rumusan Masalah}

Berdasarkan latar belakang masalah di atas, dapat disusun permasalahan sebagai berikut:

a. Apakah kualitas audit berpengaruh positif terhadap penerimaan opini audit going concern?;

b. Apakah kondisi keuangan berpengaruh negatif terhadap penerimaan opini audit going concern?;

c. Apakah ukuran perusahaan berpengaruh negatif terhadap penerimaan opini audit going concern?.

\subsection{Tujuan Penelitian}

Berdasarkan permasalahan yang telah diuraikan di atas, maka tujuan penelitian ini adalah:

a. Untuk mengetahui pengaruh positif kualitas audit terhadap penerimaan opini audit going concern;

b. Untuk mengetahui pengaruh negative kondisi keuangan terhadap penerimaan opini audit going concern;

c. Untuk mengetahui pengaruh negative ukuran perusahaan terhadap penerimaan opini audit going concern.

\section{KAJIAN PUSTAKA}

\subsection{Teori Agensi}

Penelitian ini menggunakan teori agensi yang dikembangkan oleh Michael Johnson (seorang profesor dari Harvard) yang memandang bahwa opini audit going concern, agen bertugas menjalankan perusahaan dan menghasilkan laporan keuangan sebagai bentuk dari pertanggungjawaban manajemen. Laporan 
keuangan ini yang nantinya akan menunjukkan kondisi perusahaan. Auditor mempunyai tugas dalam memberikan jasa untuk menilai kewajaran laporan keuangan perusahaan, dengan hasil akhirnya adalah opini audit. Opini audit yang dikeluarkan auditor ini haruslah yang berkualitas yang ditunjukkan dengan semakin objektif dan transparannya informasi keuangan perusahaan (Astuti, 2012).

\subsection{Pengembangan Hipotesis}

\subsubsection{Keterkaitan Kualitas Audit Terhadap Penerimaan Opini Audit Going Concern}

Menurut Rahman dan Siregar (2012), auditor dengan skala besar memiliki insentif untuk mendeteksi dan melaporkan masalah going concern kliennya. Auditor skala besar dapat menyediakan kualitas audit yang lebih baik dibanding auditor skala kecil, termasuk dalam mengungkapkan masalah going concern. Semakin besar skala auditor, akan semakin besar kemungkinan auditor untuk menerbitkan opini audit going concern. Maka, kualitas audit yang tinggi akan membuat perusahaan lebih menerima opini audit going concern.

Berdasarkan uraian tersebut, maka hipotesis yang diajukan adalah sebagai berikut :

$\mathbf{H}_{1}$ : Kualitas audit berpengaruh positif terhadap penerimaan opini audit going concern.

\subsubsection{Keterkaitan Kondisi Keuangan Terhadap Penerimaan Opini Audit Going Concern}

Carcello et al (dalam Rahman dan Siregar, 2012) mengatakan bahwa kondisi keuangan perusahaan yang terganggu, maka besar kemungkinan perusahaan tersebut akan menerima opini audit going concern. Menurut Fleak dan Wilson (dalam Indira Januarti, 2007 ), opini going concern yang tidak diinginkan ini mengakibatkan jatuhnya harga saham. Hal ini akan menunjukkan gejala kebangkrutan dan menyebabkan perusahaan sulit untuk mendapatkan modal.

Berdasarkan uraian tersebut, maka hipotesis yang diajukan adalah sebagai berikut :

H2: Kondisi keuangan berpengaruh negatif terhadap penerimaan opini audit going concern.

\subsubsection{Keterkaitan Ukuran Perusahaan Terhadap Penerimaan Opini Audit Going Concern}

Menurut penelitian yang dilakukan oleh Wuryatiningsih (dalam Alichia,2013) berpendapat bahwa total aktiva dipilih sebagai proksi atas ukuran perusahaan dengan mempertimbangkan bahwa nilai aktiva relatif lebih stabil dibanding nilai market capitalized dan penjualan. Mutchler et al (dalam Santosa dan Wedari, 2007) dalam penelitian faktor-faktor yang berpengaruh terhadap laporan audit pada perusahaan yang gulung tikar, memberikan bukti empiris bahwa ada hubungan negatif antara ukuran perusahaan dengan penerimaan opini audit going concern.

Berdasarkan uraian tersebut, maka hipotesis yang diajukan adalah sebagai berikut:

H3: Ukuran perusahaan berpengaruh negatif terhadap penerimaan opini audit going concern.

Gambar 1. menjelaskan hubungan empiris antara kualitas audit, kondisi keuangan dan ukuran perusahaan terhadap penerimaan opini audit going concern.

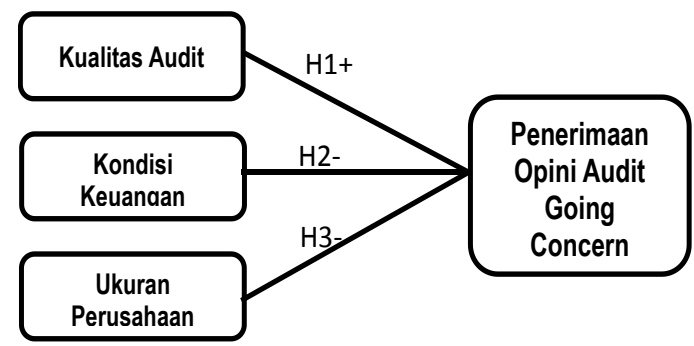

Gambar 1. Model Empiris

\section{METODE PENELITIAN}

Populasi dalam penelitian ini adalah seluruh perusahaan go public yang terdaftar di Bursa Efek Indonesia (BEI) yang bergerak dalam bidang Transportation pada tahun 2014-2016. Teknik pengambilan sampel menggunakan metode purposive sampling. Dimana peneliti menentukan sampel berdasarkan persyaratan sampel yang diperlukan.

Adapun persyaratan sebagai berikut :

1. Perusahaan sektor transportasi yang sudah terdaftar di Bursa Efek Indonesia sebelum pada 2014-2016. 
2. Perusahaan sektor transportasi yang menerbitkan laporan keuangan beserta laporan auditor independen selama periode penelitian 2014-2016.

3. Perusahaan sektor transportasi yang menyajikan laporan keuangan menggunakan kurs rupiah (Rp).

Uji hipotesis dilakukan dengan cara uji signifikansi (pengaruh nyata) variabel independen $(\mathrm{X})$ terhadap variabel dependen (Y). Dalam penelitian ini digunakan analisis regresi linear berganda. Analisis regresi digunakan oleh peneliti apabila bermaksud meramalkan bagaimana keadaan (naikturunnya) variabel dependen, dan apabila dua atau lebih variabel independen sebagai prediktor dimanipulasi atau dinaik turunkan nilainya.

Untuk pengujian hipotesis yaitu dengan menggunakan analisis regresi berganda, berikut model regresi tersebut:

$\mathrm{Z}=0,717 \mathrm{Z} 1+0,847 \mathrm{Z} 2+3,107 \mathrm{Z} 3+0,420 \mathrm{Z} 4$

$$
+0,998 \mathrm{Z} 5
$$

Keterangan Persamaan Regresi Berganda disampaikan pada tabel 3.1 berikut ini:

Tabel 3.1

Penjelasan Persamaan Regresi Berganda

\begin{tabular}{|l|l|}
\hline \multicolumn{1}{|c|}{ Simbol } & \multicolumn{1}{c|}{ Keterangan } \\
$Z$ Z1 & $\begin{array}{l}\text { working capital / total asset } \\
\text { retained earnings / total asset } \\
\text { Z3 }\end{array}$ \\
Zarnings before interest and \\
taxes / total asset \\
Z5
\end{tabular}

\section{HASIL DAN PEMBAHASAN}

\subsection{Menilai Kelayakan Model Regresi}

Langkah awal untuk mengetahui bahwa suatu model regresi logistik merupakan sebuah model yang tepat, terlebih dahulu akan dilihat bentuk kecocokan atau kelayakan model secara keseluruhan. Dalam hal ini digunakan uji Hosmer and Lemeshow's test Output pada uji Hosmer and Lemeshow's test dapat dilihat pada Tabel berikut:

Hosmer and Lemeshow Test

\begin{tabular}{|l|r|r|l|}
\hline Step & Chi-square & df & Sig. \\
\hline 1 &, 000 & 3 & 1,000 \\
\hline
\end{tabular}

Berdasarkan tabel pengujian Hosmer and Lemeshow's test di atas terlihat bahwa nilai signifikansi sebesar 1.000 lebih besar dari alpha $(\alpha=0.05)$ maka Ho diterima. Hal ini berarti model regresi layak untuk digunakan dalam analisis selanjutnya, karena tidak ada perbedaan yang nyata antara klasifikasi yang diprediksi dengan klasifikasi yang diamati. Atau dapat dikatakan bahwa model mampu memprediksi nilai observasinya.

\subsection{Menilai model Fit (Overall Model Fit Test)}

Adanya pengurangan nilai antara 2LL awal (initial-2LL function) dengan nilai $2 \mathrm{LL}$ pada langkah berikutnya menunjukkan bahwa model yang dihipotesiskan fit dengan data. Log Likehood pada regresi logistik mirip dengan pengertian "Sum of square Error" pada model regresi, sehingga penurunan Log Likehood menujukkan model regresi logistik semakin baik.

Hal ini terlihat pada tabel dibawah ini :

Iteration History $\mathrm{y}^{\mathrm{a}, \mathrm{b}, \mathrm{c}, \mathrm{d}}$

\begin{tabular}{|c|c|c|c|c|c|c|}
\hline \multirow{2}{*}{\multicolumn{2}{|c|}{ Iteration }} & \multirow{2}{*}{$\begin{array}{c}-2 \text { Log } \\
\text { likelihood }\end{array}$} & \multicolumn{4}{|c|}{ Coefficients } \\
\hline & & & Constant & $\mathrm{X} 1(1)$ & $\mathrm{X} 2$ & $\mathrm{X} 3$ \\
\hline \multirow[t]{20}{*}{ Step 1} & 1 & 27,957 & $-5,957$ & ,374 & ,043 & ,269 \\
\hline & 2 & 23,205 & $-9,414$ & ,961 & ,085 & ,411 \\
\hline & 3 & 13,820 & $-6,200$ & 1,485 &, 335 & ,298 \\
\hline & 4 & 7,669 & $-10,687$ & 1,386 & ,663 &, 481 \\
\hline & 5 & 4,835 & $-14,529$ & 1,159 & 1,047 & 647 \\
\hline & 6 & 3,089 & $-15,948$ & .492 & 1,605 &, 735 \\
\hline & 7 & 1,806 & $-18,689$ & $-1,312$ & 2,452 & ,907 \\
\hline & 8 &, 813 & $-22,948$ & $-4,993$ & 3,837 & 1,188 \\
\hline & 9 &, 324 & $-28,563$ & $-9,634$ & 5,494 & 1,548 \\
\hline & 10 &, 123 & $-35,100$ & $-14,694$ & 7,267 & 1,954 \\
\hline & 11 &, 046 & $-42,100$ & $-19,933$ & 9,093 & 2,383 \\
\hline & 12 & .017 & $-49,321$ & $-25,237$ & 10,938 & 2,822 \\
\hline & 13 &, 006 & $-56,671$ & $-30,569$ & 12,792 & 3,266 \\
\hline & 14 &, 002 & $-64,107$ & $-35,916$ & 14,651 & 3,714 \\
\hline & 15 & .001 & $-71,607$ & $-41,274$ & 16,513 & 4,165 \\
\hline & 16 &, 000 & $-79,156$ & $-46,639$ & 18,379 & 4,617 \\
\hline & 17 &, 000 & $-86,742$ & $-52,011$ & 20,246 & 5,071 \\
\hline & 18 &, 000 & $-94,358$ & $-57,387$ & 22,115 & 5,527 \\
\hline & 19 &, 000 & $-101,995$ & $-62,767$ & 23,986 & 5,983 \\
\hline & 20 &, 000 & $-109,650$ & $-68,149$ & 25,857 & 6,440 \\
\hline \multicolumn{7}{|c|}{ a. Method: Enter } \\
\hline \multicolumn{7}{|c|}{ b. Constant is included in the model. } \\
\hline \multicolumn{7}{|c|}{ c. Initial-2 Log Likelihood: 43,645} \\
\hline \multicolumn{7}{|c|}{$\begin{array}{l}\text { d. Estimation terminated at iteration number } 20 \text { because maximum iterations has } \\
\text { been reached. Final solution cannot be found. }\end{array}$} \\
\hline
\end{tabular}




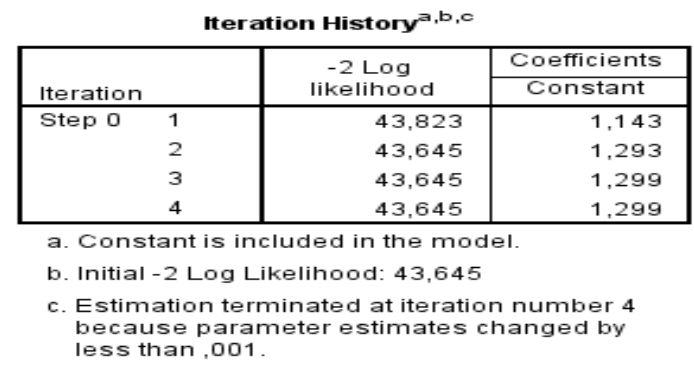

\subsection{Matrik Klasifikasi}

Matrik klasifikasi menunjukkan kekuatan prediksi dari model regresi untuk memprediksi kemungkinan penerimaan opini audit going concern pada perusahaan. Nilai matrik klasifikasi dapat dilihat pada tabel di bawah ini :

\section{Classification Table $^{\mathrm{a}}$}

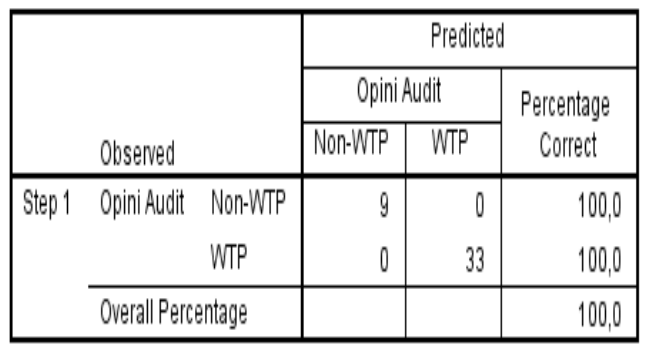

a. The cut value is , 500

Berdasarkan tabel Classification Table di atas, jumlah sampel yang tidak masuk dalam kategori Non Going Concern $9+0=9$ orang. Yang benar-benar tidak masuk dalam kategori Non Going Concern sebanyak 9 orang dan yang seharusnya tidak masuk dalam kategori Non Going Concern namun masuk, sebanyak 0 orang. Jumlah sampel yang mengalami masuk dalam kategori Going Concern $0+33=33$ orang. Yang benar-benar masuk dalam kategori Going Concern sebanyak 0 orang dan yang seharusnya masuk dalam kategori Going Concern namun tidak masuk adalah sebanyak 33 orang. Dalam Interprestasi regresi logistik dengan SPSS: Tabel di atas memberikan nilai overall percentage sebesar $(9+33) / 42=100 \%$ yang berarti ketepatan model penelitian ini adalah sebesar $100 \%$.

\subsection{Regresi Logistik}

Analisis regresi logistic dapat dilihat pada tabel Variabels in the equation, pada kolom sig dibandingkan dengan alpha $0.05(5 \%)$.
Apabila tingkat signifikansi $<0.05$ maka $\mathrm{Ha}$ diterima dan Ho ditolak. Hasil analisis regresi logistic dapat dilihat pada tabel di bawah ini:

Variables inthe Equlation

\begin{tabular}{|c|c|c|c|c|c|c|}
\hline & $B$ & SE.E. & Wald & $\sqrt{d f}$ & Silg. & $\overline{E x}(B)$ \\
\hline Step $1^{d} \quad X 1(1)$ & $.68,149$ & 17600,232 & .000 & 1 & 997 &, 000 \\
\hline$\times 2$ & 25,857 & 1124,464 & 001 & 1 & 982 & 1,696E+11 \\
\hline$\times 3$ & 6,440 & 489,533 &, 000 & 1 & 990 & 626,291 \\
\hline Constant & $.109,650$ & 11959,088 &, 000 & 1 & 993 & 000 \\
\hline
\end{tabular}

a. Varialie(s) entered on step $1: X_{1}, X_{2}, X_{3}$

Semua variabel independen nilai $\mathrm{P}$ value uji wald (Sig) > 0,05, artinya masing-masing variabel tidak mempunyai pengaruh parsial yang signifikan terhadap $\mathrm{Y}$ di dalam model. $\mathrm{X}_{1}$ atau kualitas audit mempunyai nilai Sig 0,997>0,05 sehingga menolak $\mathrm{H} 1$ atau yang berarti kualitas audit tidak berpengaruh positif terhadap penerimaan opini audit going concern. $\mathrm{X}_{2}$ atau kondisi keuangan perusahaan mempunyai nilai Sig 0,982 > 0,05 sehingga menolak $\mathrm{H}_{2}$ atau yang berarti kondisi keuangan tidak berpengaruh negatif terhadap penerimaan opini audit going concern. $\mathrm{X}_{3}$ atau ukuran perusahaan mempunyai nilai Sig 0,990>0,05 sehingga menolak $\mathrm{H}_{3}$ atau yang berarti ukuran perusahaan tidak berpengaruh negatif terhadap penerimaan opini audit going concern.

\section{TABEL}

PENGUJIAN HIPOTESIS

\begin{tabular}{|c|c|c|c|c|}
\hline $\begin{array}{c}\text { HIPO } \\
\text { TESI } \\
\mathbf{S}\end{array}$ & PERNYATAAN & B & SIG & HASIL \\
\hline $\mathbf{H}_{1}$ & $\begin{array}{l}\text { Kualitas audit } \\
\text { berpengaruh positif } \\
\text { terhadap } \\
\text { penerimaan opini } \\
\text { audit going conce }\end{array}$ & $-68,149$ & 0,997 & DITOLAK \\
\hline $\mathbf{H}_{2}$ & $\begin{array}{l}\text { Kondisi keuangan } \\
\text { berpengaruh negatif } \\
\text { terhadap } \\
\text { penerimaan opini } \\
\text { audit going } \\
\text { concern. }\end{array}$ & 25,857 & 0,982 & DITOLAK \\
\hline $\mathbf{H}_{3}$ & $\begin{array}{l}\text { Ukuran perusahaan } \\
\text { berpengaruh negatif } \\
\text { terhadap } \\
\text { penerimaan opini } \\
\text { audit going } \\
\text { concern. }\end{array}$ & 6,440 & 0,990 & DITOLAK \\
\hline
\end{tabular}




\subsection{Pengujian Hipotesis}

4.5.1. Pengaruh Kualitas Audit Terhadap Opini Audit Going Concern (GCOA)

Hasil pengujian hipotesis menunjukkan bahwa kualitas audit tidak berpengaruh terhadap opini audit going concern. Hasil pengujian hipotesis menunjukkan bahwa KAP the big four tidak mempengaruhi pemberian opini audit going concern. Kantor Akuntan Publik (KAP) yang berafiliasi dengan KAP the big four atau KAP yang tidak berafiliasi dengan KAP the big four sama-sama mempunyai porsi atau peluang yang sama dalam memberikan opini audit going concern. KAP yang memiliki reputasi baik maka KAP tersebut akan berusaha mempertahankan reputasinya dan menghindari hal-hal yang dapat merusak reputasi baiknya, sehingga KAP tersebut akan selalu bersikap obyektif terhadap pekerjaan agar reputasinya tetap terjaga. Dalam hal ini berarti KAP yang berafiliasi dengan KAP the big four atau KAP yang tidak berafiliasi dengan KAP the big four sama-sama memberikan kualitas audit yang baik dan tetap bersifat independen dalam memberikan opini audit going concern. Kualitas audit yang baik akan menghasilkan informasi yang sangat berguna bagi para pemakai laporan keuangan dalam hal pengambilan keputusan, oleh karena itu, auditor bertanggung jawab untuk menyediakan jasa audit yang berkualitas. Hasil penelitian ini tidak sejalan dengan penelitian Barlian dkk (2014) dan Krisindiastuti dan Rasmini (2016) yang menyatakan bahwa kualitas audit berpengaruh terhadap opini audit going concern, namun hasil penelitian ini sejalan dengan temuan Junaidi dan Hartono (2010) dan Hongaluant (2014).

\subsubsection{Pengaruh Kondisi Keuangan Terhadap Opini Audit Going Concern (GCOA)}

Hasil pengujian hipotesis menunjukkan bahwa kondisi keuangan tidak berpengaruh terhadap opini audit going concern. Auditor biasanya akan mempertimbangkan kondisi keuangan ketika memberikan opini audit going concern. Kondisi keuangan yang buruk akan mendorong auditor untuk cenderung memberikan opini audit going concern. Hasil pengujian regresi logistik menolak $\mathrm{H}_{2}$ karena tidak terbukti secara signifikan sehingga dapat dinyatakan bahwa kondisi keuangan tidak meningkatkan kemungkinan perusahaan menerima opini audit going concern. Kondisi ini terjadi ketika auditor mempertimbangkan faktor lain seperti kondisi ekonomi atau pertumbuhan perusahaan. Hasil ini mendukung penelitian Ardiani dkk (2012 dan Khotimah (2015) yang menyatakan bahwa kondisi keuangan perusahaan tidak berpengaruh signifikan terhadap opini audit going concern.

\subsubsection{Pengaruh Ukuran Perusahaan Terhadap Opini Audit Going Concern (GCOA)}

Hasil pengujian hipotesis menunjukkan bahwa ukuran perusahaan tidak berpengaruh terhadap opini audit going concern. Hasil penelitian ini memberikan bukti empiris bahwa ukuran perusahaan tidak mempunyai pengaruh terhadap penerimaan opini audit going concern. Berarti klasifikasi ukuran perusahaan besar ataupun kecil dengan indikator total aset yang dimiliki tidak menjadi penentu auditor akan menerbitkan opini audit going concern, perusahaan kecil belum tentu tidak bisa menjalankan usahanya dalam jangka panjang. Kelangsungan hidup usaha biasanya dihubungkan dengan kemampuan manajemen dalam mengelola perusahaan agar tetap bertahan hidup. Oleh karena itu, meskipun suatu perusahaan tergolong dalam perusahaan kecil akan tetap bertahan hidup dalam jangka waktu yang panjang karena memiliki manajemen dan kinerja yang bagus sehingga semakin kecil potensiperusahaan mendapatkan opini audit going concern. Hasil penelitian ini tidak sejalan dengan penelitian yang dilakukan Aiisiah (2012), Alichia (2013), Barlian dkk (2014) dan Ginting dan Suryana (2014) yang menyatakan bahwa ukuran perusahaan berpengaruh terhadap penerimaan opini audit going concern.

\section{KESIMPULAN DAN SARAN}

Berdasarkan hasil uji regresi logistik (logistic regression), terbukti bahwa kualitas audit, kondisi keuangan, dan ukuran perusahaan tidak berpengaruh terhadap penerimaan opini audit going concern. Sampel penelitian ini adalah semua sektor perusahaan yang terdaftar di Bursa Efek Indonesia (BEI) 
dalam sektor transportasi pada tahun 2014 sampai dengan 2016 dengan menggunakan metode Purposive Sampling, sehingga menghasilkan sampel 14 perusahaan dengan rincian 9 perusahaan memperoleh opini audit non going concern dan 33 perusahaan memperoleh opini audit going concern, diolah menggunakan SPSS (Statistic Package For the Social Science) versi 23 dan dianalisis dengan regresi logistik.

Hasil penelitian ini diharapkan dapat memberikan gambaran tentang pengaruh kualitas audit, kondisi keuangan, dan ukuran perusahaan terhadap opini audit going concern (GCOA). Saran yang dapat dipertimbangkan bagi peneliti yang akan datang:

1. Penelitian ini menggunakan sampel seluruh sektor perusahaan yang terdaftar di Bursa efek Indonesia (BEI) dalam sektor trasnportasi periode pengamatan 2014-2016 (selama 3 tahun). Untuk peneliti selanjutnya akan lebih baik jika memperpanjang tahun pengamatan. Sehingga menghasilkan sampel yang lebih banyak supaya dapat memperoleh suatu hasil yang lebih baik dan mendekati kondisi yang sebenarnya.

2. Pada penelitian ini, penulis tidak menggunaan faktor opini audit tahun sebelumnya, auditor client tenure, audit change, audit lag, opinion shopping, debt default, financial distress, dan arus kas. Faktor-faktor tersebut dapat digunakan untuk mempengaruhi pemberian opini audit going concern. sebaiknya peneliti selanjutnya dapat menggunakan faktor-faktor tersebut sebagai variabel independen yang pada akhirnya dapat mendapatkan lebih banyak variabel yang berpengaruh signifikan.

\section{DAFTAR PUSTAKA}

Azizah, R. dan I. Anisykurlillah.2014. Pengaruh Ukuran Perusahaan, Debt Default, dan Kondisi Keuangan Perusahaan Terhadap Penerimaan Opini Audit Going Concern. Accounting Analysis Journal 2(1): 1-4.

Hani, Cleary, dan Mukhlasin. 2003. Going Concern dan Opini Audit: Suatu Studi Pada
Perusahaan Perbankan Di BEJ. Simposium Nasional Akuntansi 4: 1221-1233. Jakarta.

Rahman, A. dan B. Siregar. 2012. FaktorFaktor Yang Mempengaruhi Kecenderungan Penerimaan Opini Audit Going Concern pada Perusahaan Manufaktur yang Terdaftar di Bursa Efek Indonesia. Simposium Nasional Akuntansi 15: 1-37. Yogyakarta 